\title{
J-REIT 所有オフィスにおける CASBEE 認証及び東京都トップレベル事業所 認定が賃貸事業収益及び水道光熱費に与える影響 \\ EFFECTS OF CASBEE AND TOKYO METROPOLITAN GOVERNMENT \\ TOP LEVEL CERTIFICATES ON THE NET OPERATING INCOME AND UTILITY EXPENSES IN J-REIT OWNED OFFICE BUILDINGS
}

\author{
青木 現*, 田辺新一 ${ }^{* *}$, 板谷敏正 ${ }^{* * *}$ \\ Gen AOKI, Shin-ichi TANABE and Toshimasa ITAYA
}

\begin{abstract}
The purpose of this research is to evaluate the situation of Top-Level Business Facility and CASBEE certified buildings by using the data of j-reit owned office buildings. Regarding the objective office, the total leased area is under $50000 \mathrm{~m}^{2}$ and total building area is over $10000 \mathrm{~m}^{2}$. The net operating income of Top-Level Business Facility and CASBEE certified office buildings is bigger than that of not certified office buildings. The utilities cost of Top-Level Business Facility certified office buildings is the same as that of not certified office buildings, but the utilities cost of CASBEE certified office buildings is bigger than that of not certified office buildings. The net operating income of expired CASBEE certified office buildings is bigger than that of not certified office buildings. The utilities cost of expired CASBEE certified office buildings is the same as that of not certified office buildings. Using these results, the environmental performance of Top-Level Business Facility certified office buildings and expired CASBEE certified office buildings may be high in the value of the real estate.
\end{abstract}

Keywords : CASBEE, Tokyo M etropolitan Government Top Level Certificate, J-REIT, Office Buildings, Net O perating Income, Utilities Cost, CASBEE，東京都トップレベル事業所，J-REIT，事務所，NOI，水道光熱費

1. はじめに

近年、日本における消費エネルギー量は、オフィスや商業施設を 中心とした業務部門の増加が顕著であり、オフィスにおける省エネ ルギー対策の強化が求められている ${ }^{1)}$ 。そこで、不動産として建物 の省エネルギー性などの環境性能を認証する制度が提案されている。 代表的な例として、CASBEE（建築環境総合性能評価システム）2)や 米国を中心としたグリーンビルディングの認証プログラム $\mathrm{LEED}^{3)}$ 東京都トップレベル事業所などがある。東京都トップレベル事業所 （優良特定地球温暖化対策事業所）とは、地球温暖化の対策の推進 の程度が特に優れた事業所として、都知事が定める基準に適合寸る と知事が認めたとき、当該対象事業所の削減義務率を地球温暖化の 対策の推進の程度に応じて軽減する仕組みである ${ }^{4)}$

企業の社会的な責任 $(\mathrm{CSR})$ の観点からの取り組みとしての環境 対策が実施されはじめている。しかしながら、それらの評価のあり 方や情報不足などにより、市場での評価が伴っているとは必ずしも いえない5)。環境認証によっては評価基準が公表されていない場合
があるほか、経済的効果が定量的に示されていないことが原因と考 えられる。環境性能の高い不動産の促進には、経済性や快適性の向 上あるいは周辺環境との調和など環境性能向上により得られる様々 な付加価值を明確にする必要があり、とりわけテナントがもっとも 関心を抱く項目であり、省エネルギー化により削減される水道光熱 費についてはその効果の定量化が求められている ${ }^{6}$ 。

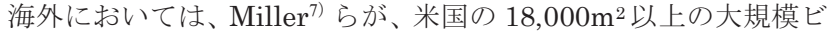
ルにおいて、Energy STAR や LEED の認証物件は非認証物件と比 較して、貨料や稼働率が高いことを示している。Quigley $\left.{ }^{8}\right)$ らは、米 国の Energy STAR や LEED の認証を取得した商業施設は、非認証 の施設と比較して賃料が約 $3 \%$ 高いことを示した。

日本では吉田ら 9) が、独自の東京 23 区のオフィスデータを用い て、規模、新しさ、立地、成約時期、他の性能・設備などの影響を 除いても、環境認証は新規成約賃料に約 $4.4 \%$ プラスの影響を与える ことを示した。伊藤 10) は、オーナー等のヒアリング調查から全国の オフィスビルの推定成約賃料を推定し、規模、新しさ、立地、空室率

\footnotetext{
* 元早稲田大学大学院創造理工学研究科 大学院生 ·工修

** 早稲田大学創造理工学部建築学科 教授・工博

*** プロパティデータバンク(株) 博士(工学)
}

Former Grad. Stud., Waseda University

Prof., Dept. of Architecture, Waseda University, Dr.Eng.

Property Data Bank, Inc., Dr.Eng. 
などの影響を除いても、CASBEE 認証を受けた偊貸オフィスビルは 共益費込賃料が平均推定成約賃料に対して $3.64 \%$ プラスの影響を与 えることを示した。また、CASBEE 認証のランクによる差を評点化 して分析したところ、1 ランク上昇するごとに 264 円/月・坪 (平均賃 料比約 $1.7 \%$ ) 上昇する推計結果を得ている。画期的な研究であるが 成約貨料のみの検討であり、収益や費用の内訳は明確にされていない。

一方で、環境認証が不動産の収益や費用の内訳に与える影響につ いて、DBJ 認証の有無による水道光熱費や不動産収益の研究が行わ れているが、認証による差異は明確に示されていない11) 12)。

本研究では、収益や費用の内訳が公開されている J-REIT (Japan Real Estate Investment Trust）投資法人が公開しているデータを 用いて、CASBEE 認証及び東京都トップレベル事業所認定の有無が オフィスビルの年間賃貸事業収益（NOI : Net Operating Income、 以下 NOI と呼ぶ）注1) 及び水道光熱費に与える影響を解析すること を目的とした。本研究で対象とした CASBEE 認証及び東京都トッ プレベル事業所認定の取得物件は一定の環境性能を有していると考 えられる。本報では、CASBEE 認証及び東京都トップレベル事業所 認定の有無が収益や費用に与える影響を知るため、J-REIT の公開 資料に記載された用途や建物規模などの影響を考慮して解析した。

\section{J-REIT 所有オフィスの調査方法と調査概要}

本研究の解析では、2014 年度 12 月時点の J-REIT 所有オフィス の直近 2 期分のデータ ( 1 年間の積算值) を用いた。J-REIT は、多 くの投資家から集めた資金で不動産を購入し、その賃貸収入を投資 家に分配する商品である ${ }^{13}$ )。金融庁による指導もあり、投資家への 情報開示が充実しており、半年毎に発行される有価証券報告書等に 詳細な建物情報、賃料情報が記載されている。

本報の対象物件は賃貸事業のために運用される物件であり、不動 産の価值は不動産の収益が基本となっていると考え、NOI を指標と して採用した。NOI は、賃貸事業収入から賃貸事業費用を引いたも のである。不動産の時価評価額や取引価格を用いることも可能であ るが、これらの価格はNOIに基づき算定されている。また、NOIか ら減価償却費を差し引くと賃貸事業利益となる。減価償却費は建物 部分のみに適用される。土地と建物部分で得られる収入の合計に対 する減価償却費の割合は物件によって異なるため、本報では賃貸事 業利益ではなく NOIによる解析を行った。また、水道光熱費は国土 交通省の調查 ${ }^{14)}$ によると、コストの中でもテナントが最も関心をも つ費用であり、省エネルギー性に大きく関与寸る項目であることか ら解析対象とした。しかし、水道光熱費はエネルギー源、契約形態、 契約料金の相違により必ずしもエネルギー消費量と同等となるとは 限らない。そのため、CASBEE 認証物件で一次エネルギー消費量実 績值が公開されている事例に関して両者を比較することとした。

対象投資法人は、 2014 年の時点で運用資産にオフィスを含む投資 法人す心゙てとした。解析した全物件の主要途はオフィスであるが、 賃貸部分の一部が住居や商業施設の用途で使われている物件も含ま れる。そのような物件は総貸貸面積が $50,000 \mathrm{~m}^{2}$ 以上の場合に多く、 5 物件を対象から除いた。

\section{1 投資法人別の対象件数}

表 1 に解析投資法人と対象とした物件数を示す。調査対象とした 投資法人は、計 24 法人である。対象物件の合計は、全国で 651
表 1 解析対象法人と物件数

\begin{tabular}{|c|c|c|c|}
\hline 解析法人 & 全国 & 東京 & 都心5区 \\
\hline MCUBS MidCit投資法人 & 8 & 0 & 0 \\
\hline SIA不動産投資法人 & 17 & 10 & 2 \\
\hline アクティビア・プロパティーズ投資法人 & 11 & 9 & 7 \\
\hline いちごオフィスリート投資法人 & 44 & 30 & 21 \\
\hline インヴィンシブル投資法人 & 5 & 4 & 2 \\
\hline オリックス不動産投資法人 & 39 & 29 & 19 \\
\hline グローバル・ワン不動産投資法人 & 10 & 7 & 5 \\
\hline ケネディクス・オフィス投資法人 & 75 & 54 & 39 \\
\hline ジャパンエクセレント投資法人 & 28 & 16 & 10 \\
\hline ジャパンリアルエステイト投資法人 & 62 & 37 & 29 \\
\hline トップリート投資法人 & 10 & 10 & 9 \\
\hline プレミア投資法人 & 23 & 20 & 15 \\
\hline ユナイテッド・アーバン投資法人 & 36 & 18 & 14 \\
\hline $\begin{array}{l}\text { 阪急リート投資法人 } \\
\end{array}$ & 3 & 1 & 1 \\
\hline 森トラスト総合リート投資法人 & 7 & 5 & 3 \\
\hline 森ヒルズリート投資法人 & 5 & 5 & 4 \\
\hline 大和証券オフィス投資法人 & 40 & 36 & 31 \\
\hline 東急リアル・エステート投資法人 & 17 & 17 & 12 \\
\hline 日本ビルファンド投資法人 & 71 & 44 & 33 \\
\hline 日本プライムリアルティ投資法人 & 47 & 29 & 21 \\
\hline 日本リート投資法人 & 11 & 11 & 9 \\
\hline 福岡リート投資法人 & 5 & 0 & 0 \\
\hline 平和不動産リート投資法人 & 23 & 18 & 12 \\
\hline 野村不動産マスターファンド投資法人 & 54 & 34 & 21 \\
\hline 合計（解析対象） & 651 & 444 & 319 \\
\hline
\end{tabular}

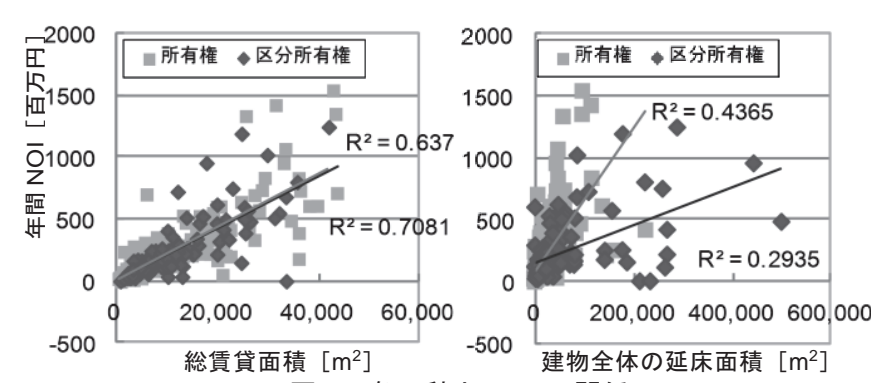

図 1 各面積と NOI の関係

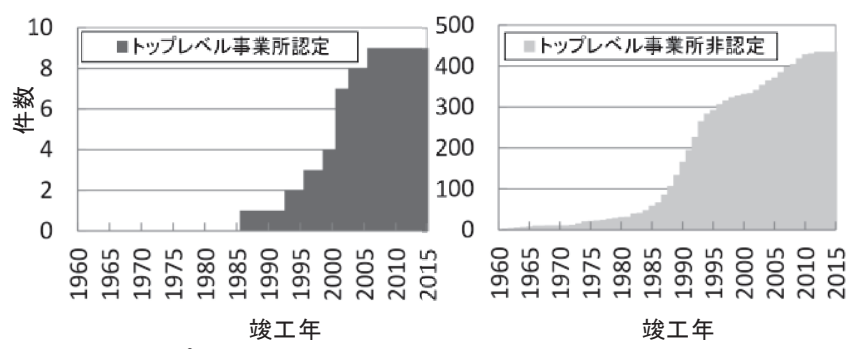

図 2 トップレベル事業所認定有無による竣エ年と件数 (積算値)
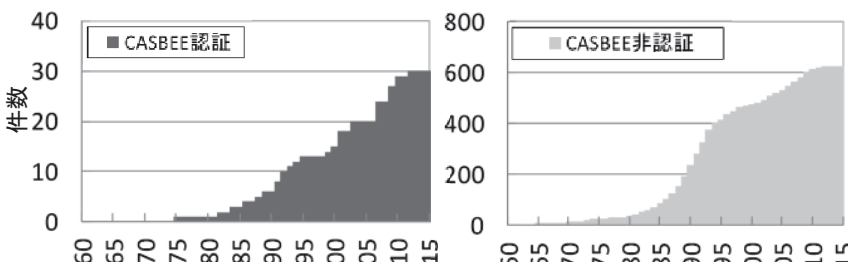

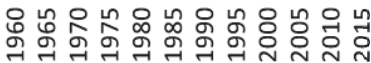
竣工年

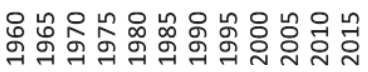
竣工年

図 3 CASBEE 認証有無による竣工年と件数（積算値）

件、東京都で 444 件、都心 5 区 (新宿区、渋谷区、千代田区、港区、 中央区）で 319 件である。

\section{2 解析方針}

図 1 に総賃貸面積および建物全体の延床面積と NOI の関係を示 
す。総貨貸面積は、総賃貸可能面積に稼働率を乗じたものである。 J-REIT 保有オフィスには超高層ビルや複合施設が存在し、建物の 一部だけを所有している場合がある。解析対象における一棟所有も しくは共有のオフィスは 517 件、区分所有のオフィスは 138 件であ った。総貨貸面積と NOI の関係では、所有形態の違いによる NOI の差はほとんど見られなかった。一方、建物全体の延床面積と NOI の関係では、所有権と比較して区分所有権の NOI が顕著に低かっ た。本研究では所有形態による賃貸事業収益の差異をできるだけ少 なくするため、総貨貸面積と NOI の関係を解析することとした。一 方、不動産の賃貸事業収益は建物のグレードや立地特性、築年数な どの影響も考えられる。本報で解析したデータは都心 5 区において、 CASBEE 認証物件の平均路線価が $2120\left(千 円 / \mathrm{m}^{2}\right)$ に対して、非認 証物件の平均路線価は $2308\left(千 円 / \mathrm{m}^{2}\right)$ であった。また、トップレ ベル事業所認証物件の路線価平均は $1931\left(千 円 / \mathrm{m}^{2}\right)$ 、同非認証物件 の平均路線価は $2310\left(千 円 / \mathrm{m}^{2}\right)$ であった。CASBEE 環境認証を取 得した物件の路線価の平均值は、非認証物件の平均值よりも低い結 果となり、認証物件の賃貸事業収益が高い理由は地価以外にあると 推測される。そのため、CASBEE 認証およびトップレベル事業所認 定の有無による立地条件には大きな差異がないと考えた。

各物件の規模による影響も考慮するため、J-REIT 保有オフィス を、社団法人日本ビルヂング協会連合会の定義を参考に、小規模 (建 物全体の延床面積 $3,000 \mathrm{~m}^{2}$ 未満）、中規模（建物全体の延床面積 $3,000 \mathrm{~m}^{2}$ 以上、 $10,000 \mathrm{~m}^{2}$ 未満)、大規模（建物全体の延床面積 $10,000 \mathrm{~m}^{2}$ 以上）に分類した。

\section{3 竣工年と対象物件積算値の推移}

図 2 に東京都におけるトップレベル事業所認定有無による竣工年 と件数（積算值）を、図 3 に全国における CASBEE 認証有無によ る竣工年と件数（積算值）を示す。対象とした CASBEE 認証の詳 細は 4 項に示す。トップレベル事業所認定物件は 9 件、トップレベ ル事業所非認定物件は 435 件、CASBEE 認証物件は 32 件、CASBEE 非認証物件は 619 件となった。トップレベル事業所認定物件は 9 件 であったが、1990 年代以前に竣工した物件も存在した。CASBEE 認証物件と比較して、非認証物件は 1985 1995 年に竣工した物件 の割合がやや多かった。環境認証物件と非認証物件で、竣工年の分 布に大きな差はなかった。

\section{3. トップレベル事業所認定と NOI の関係}

\section{1 調查対象}

東京都トップレベル事業所認定は、地球温暖化対策の推進レベル に応じてトップレベル事業所と準トップレベル事業所に分けられる。 いずれの事業所もトップレベル事業所認定物件として解析した。

表 2 にトップレベル事業所認定の物件一覧を示寸 ${ }^{15)}$ 。対象物件は トップレベル事業所が 2 件、準トップレベル事業所が 7 件であった。 解析したオフィス全体の用途は、事務所と複合用途に大きく分けら れる。建物全体の用途が複合用途の場合でも、賃貸部分の用途は事 務所のみの場合があった。認定物件に関して、建物全体の用途は複 合用途が多いが、賃貸部分の用途は事務所が多かった。

\section{2 解析結果}

トップレベル事業所認定物件の NOI は 9 件全て有価証券報告書 に記載されていたが、そのうち 4 件は年間水道光熱費が記載されて
表 2 トップレベル事業所認定の物件一覧注2)

\begin{tabular}{|c|c|c|c|c|c|c|}
\hline \multirow{2}{*}{ ランク } & \multirow{2}{*}{ 物件名 } & \multirow{2}{*}{ 投資法人 } & \multirow{2}{*}{ 住所 } & \multicolumn{2}{|c|}{ 用途 } & \multirow{2}{*}{$\begin{array}{l}\text { 所有形態 } \\
\text { ( 建物) }\end{array}$} \\
\hline & & & & 全体 & 賃貸部分 & \\
\hline 準トップ & \begin{tabular}{|l} 
晴海アイランド \\
トリトンスクエア \\
オフィスタワーY棟
\end{tabular} & トップ & 中央区 & 事務所 & 事務所 & 区分所有権 \\
\hline 準トップ & \begin{tabular}{|l|} 
晴海アイランド \\
トリトンスクエア \\
オフィスタワーZ棟
\end{tabular} & トップ & 中央区 & 事務所 & 事務所 & 区分所有権 \\
\hline 準トップ & ゲート シティ 大崎 & 日ビル & 品川区 & 複合 & 複合 & \begin{tabular}{|l} 
区分所有権 \\
( 共有)
\end{tabular} \\
\hline 準トップ & アーク森ビル & 森ヒルズ & 港区 & 複合 & 事務所 & 区分所有権 \\
\hline トップ & 六本木ヒルズ森タワー & 森ヒルズ & 港区 & 複合 & 事務所 & \begin{tabular}{|l} 
区分所有権 \\
( 共有)
\end{tabular} \\
\hline 準トップ & 愛宕グリーンヒルズ & 森ヒ ルズ & 港区 & 複合 & 複合 & $\begin{array}{l}\text { 区分所有権 } \\
\text { ( 共有) }\end{array}$ \\
\hline 準トップ & 赤坂パークビル & リアル & 港区 & 複合 & 複合 & 所有権 \\
\hline 準トップ & グランパーク & プレミア & 港区 & 複合 & 複合 & \begin{tabular}{|l} 
所有権 \\
$($ 共有)
\end{tabular} \\
\hline トップ & 赤坂ガーデンシティ & エク & 港区 & 複合 & 事務所 & $\begin{array}{l}\text { 区分所有権 } \\
\text { ( - 部共有) }\end{array}$ \\
\hline
\end{tabular}

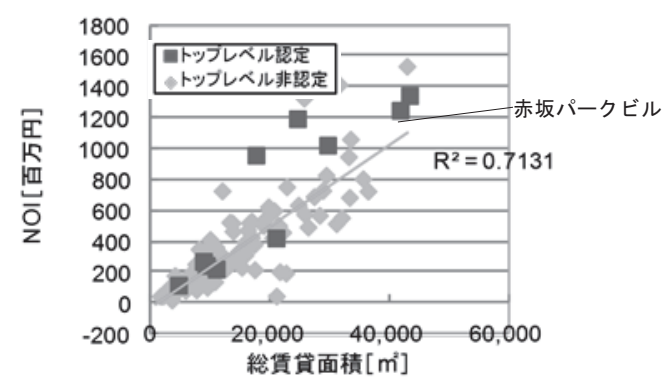

図 4 総賃貸面積と年間 NOI（トップレベル）

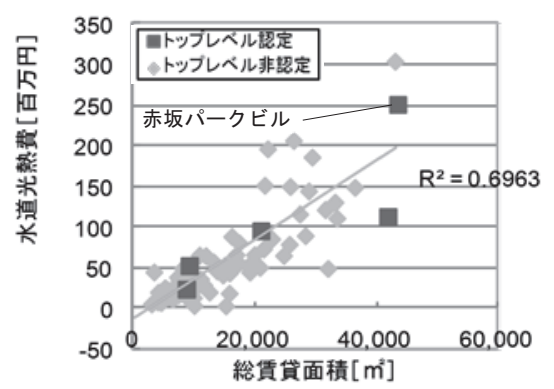

図 5 総賃貸面積と年間水道光熱費 (トップレベル)

表 3 CASBEE 認証の大規模物件一覧（有効期限内）注2)

\begin{tabular}{|c|c|c|c|c|c|c|}
\hline \multirow[b]{2}{*}{ ランク } & \multirow[b]{2}{*}{ 物件名 } & \multirow{2}{*}{ 投資法人 } & \multirow[b]{2}{*}{ 住所 } & \multicolumn{2}{|c|}{ 用途 } & \multirow{2}{*}{\begin{tabular}{|l}
$\begin{array}{l}\text { 所有形態 } \\
\text { (建物) }\end{array}$ \\
\end{tabular}} \\
\hline & & & & 全体 & 賃貸部分 & \\
\hline $\mathrm{A}$ & 後楽森ビル & 森ヒ ルズ & 東京都文京区 & 複合 & 複合 & 区分所有権 \\
\hline A & Jタワー & SIA & 東京都府中市 & 複合 & 複合 & 所有権 \\
\hline A & \begin{tabular}{|l|} 
パシフィックマーク \\
ス新宿パークサイド
\end{tabular} & ユナ & 東京都新宿区 & 複合 & 複合 & 所有権 \\
\hline A & $\begin{array}{l}\text { パシフィックマーク } \\
\text { ス横浜イースト }\end{array}$ & ユナ & $\begin{array}{l}\text { 神夸川県 } \\
\text { 横浜市 } \\
\end{array}$ & 事務所 & 事務所 & 所有権 \\
\hline A & \begin{tabular}{|l|} 
パシフィックマーク \\
ス江坂
\end{tabular} & ユナ & 大阪府吹田市 & 複合 & 複合 & 所有権 \\
\hline $\mathrm{A}$ & 烏丸ビル & ケネ & 京都府京都市 & 事務所 & 事務所 & 所有権 \\
\hline $\mathrm{A}$ & KDX新宿ビル & ケネ & 東京都新宿区 & 複合 & 複合 & 所有権 \\
\hline A & 新宿マインズタワー & 大和証券 & 東京都渋谷区 & 複合 & 複合 & $\begin{array}{l}\text { 所有権 } \\
\text { (共) }\end{array}$ \\
\hline s & アーク森ビル & 森上ル & 東京都港区 & 複合 & 事務所 & 区分所有権 \\
\hline S & \begin{tabular}{|l} 
六本木ヒルズ \\
森タワー
\end{tabular} & 森ヒ ルズ & 東京都港区 & 複合 & 事務所 & \begin{tabular}{|l} 
区分所有権 \\
(共有) \\
\end{tabular} \\
\hline $\mathrm{s}$ & 愛宕グリーンヒルズ & 森ヒ ルズ & 東京都港区 & 複合 & 複合 & \begin{tabular}{|l} 
区分所有権 \\
(共有) \\
\end{tabular} \\
\hline S & \begin{tabular}{|l} 
アークヒルズ \\
仙石山森タワー
\end{tabular} & グロ & 東京都港区 & 事務所 & 事務所 & 区分所有権 \\
\hline s & KDX小林道修町ビ ル & ケネ & 大阪府大阪市 & 複合 & 複合 & 所有権 \\
\hline s & ゲートシティ大崎 & 日本ビル & 東京都品川区 & 複合 & 複合 & \begin{tabular}{|l} 
区分所有権 \\
(共有) \\
\end{tabular} \\
\hline
\end{tabular}

いなかった。

図 4 に総賃貸面積と NOI の比較を示す。図中に示した回帰直線 
はトップレベル事業所以外の物件に対するものである。認定物件は、 非認定物件の回帰式よりも NOI が高かった。

図 5 に総賃貸面積と水道光熱費の比較を示す。認定物件は、非認 定物件と水道光熱費の差がほとんどみられなかった。これらの物件 ではテナントの企業活動が活発であると推考される。トップレベル 事業所認定物件は他物件に比べ省エネルギー性が高いため、テナン 卜の企業活動が活発でも水道光熱費は、非認定物件と同程度となっ たと推察される。一方で赤坂パークビルの水道光熱費は、認定物件 の中で顕著に高かった。赤坂パークビルは一棟所有で建物全体の用 途に店舗・住宅棟も含まれるため、事務所部分の区分所有が多いそ の他の大規模物件と比較して、水道光熱費が増大したのでないかと 推察された。

\section{CASBEE 認証と NOI（賃貸事業収益）の関係 \\ 4.1 調査対象}

CASBEE（建築環境総合性能評価システム）は建物の品質を総合 的に $\mathrm{S} \sim \mathrm{C}$ の 5 段階で評価する。CASBEE は建物用途や運用段階な どによって複数のツールに分けられ、基本ツールとして CASBEE 建築 (新築) やCASBEE 建築（既存）がある。さらに、不動産関係 者に広く使用されるように、CASBEE 不動産が 2012 年に開発され た。また、CASBEE 基本ツールやCASBEE 不動産を自治体で独自 に行う場合があり、自治体版 CASBEE と呼ばれている。本報では 全てのツールをCASBEE 認証物件として解析した。CASBEEの有 効期限は、新築で認証から 3 年、不動産や既存で認証から 5 年とな っている。

表 3 に 2014 年度の全国における有効期限内の CASBEE の大規 模物件一覧を示す。全国における CASBEE の大規模物件は、 CASBEE 不動産が 13 件、CASBEE 既存が 1 件となった。ランク は S が 6 件、A が 8 件となった。建物全体、賃貸部分ともに、複合 用途の物件が多かった。2014 年の時点で CASBEE の有効期限内の 物件を解析対象としたため、失効した物件は表に記載されていない。

表 4 に 2014 年度の全国における有効期限内の CASBEE の中規 模物件一覧を示す。全国における CASBEE の中規模物件は、全て CASBEE 不動産で 6 件となった。ランクは S が 1 件、A が 5 件と なった。建物全体、賃貸部分ともに用途は事務所の物件が多かった。 大規模、中規模とも CASBEE ランクが S、A と高い物件のみであ り、建築環境総合性能が高い物件が比較対象となっている。なお、 認証を受けた小規模物件はパシフィックマークス赤坂見附 1 件のみ であり、解析対象から除いた。

\section{2 大規模物件に関する解析結果}

図 6 に大規模物件における総貨貸面積と NOI の比較を示す。認 証物件は、非認証物件と比較して NOI が高い傾向にあった。認証物 件の建物全体用途は複合が多く、付帯部分が NOI に影響した可能 性がある。この点に関しては、今後さらなる検討が必要である。

図 7 に大規模物件における総賃貸面積と年間水道光熱費の比較を 示す。認証物件は、非認証物件と比較して水道光熱費が必ずしも低 くなっていなかった。認証物件の複合用途が店舗などで、水道光熱 費が事務所と比較して高くなった可能性がある。特に、J タワー、 新宿マインズタワー、後楽森ビルの水道光熱費が顕著に高いことが 影響している。新宿マインズタワーと Jタワーは地域冷暖房を導入
表 4 CASBEE 認証の中規模物件一覧（有効期限内） 注 2)

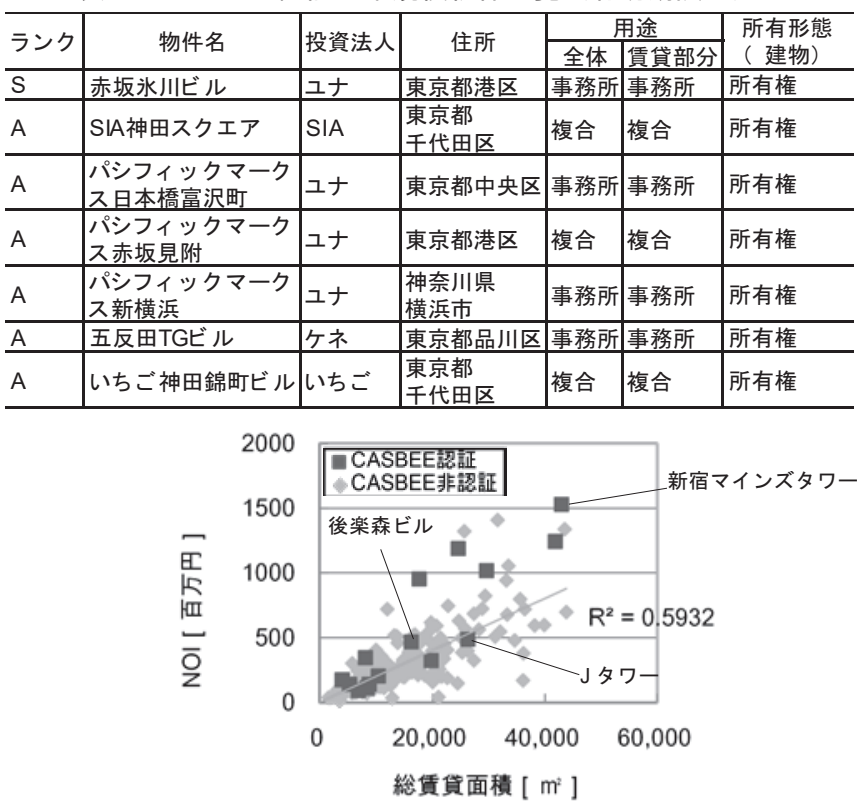

図 6 大規模物件の総賃貸面積と年間 NOI（有効期限内）

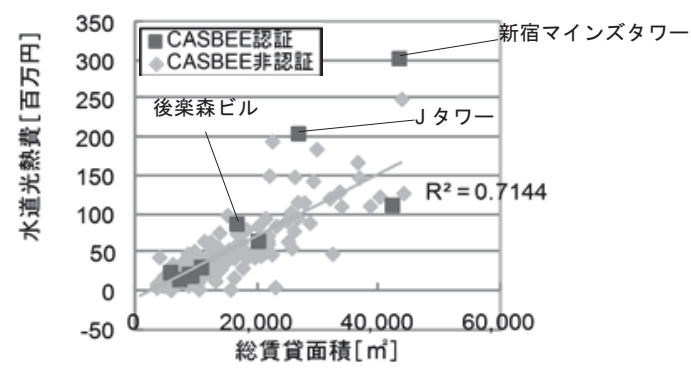

図 7 大規模物件の総賃貸面積と年間水道光熱費（有効期限内）

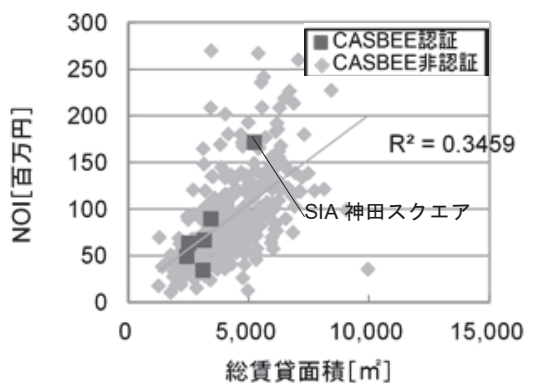

図 8 中規模物件の総賃貸面積と年間 NOI（有効期限内）

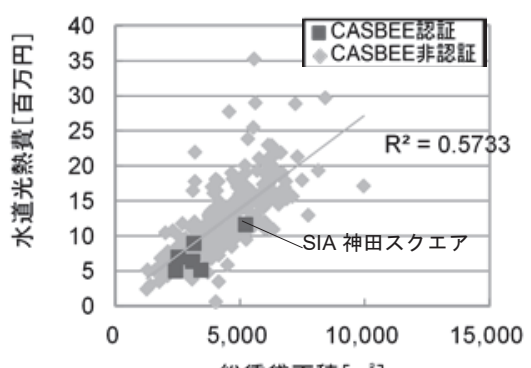

図 9 中規模物件の総賃貸面秷賃貸面間水道光熱費（有効期限内）

しているほか、複合用途かつ一棟所有であり、店舗等により水道光 熱費が大きく増加したと考えられる。新宿マインズタワーと後楽森 ビルは他の CASBEE 認証物件と比較してNOIが高かった。一方で、 J タワーの NOI は CASBEE 非認証物件と同程度であった。J タワ 
ーは 2014 年の時点で CASBEE 認証取得 1 年目のため影響が遅行 している可能性が考えられる。

\section{3 中規模物件に関する調査結果}

図 8 に中規模物件における総債貸面積と年間 NOI の比較を示す。 認証物件の NOI は、総貸貸面積が $5,000 \mathrm{~m}^{2}$ を唯一超える SIA 神田 スクエアが、非認証物件と比較して顕著に高い結果を示した。一方 で、他の CASBEE 認証物件は、非認証物件とほとんど差が見られ なかった。

図 9 に中規模物件における総賃貸面積と年間水道光熱費の比較を 示す。認証物件の水道光熱費は、総賃貸面積が $5,000 \mathrm{~m}^{2}$ を唯一超え るSIA 神田スクエアが、非認証物件と比較して顕著に低い結果を示 した。他の CASBEE 認証物件も、総じて水道光熱費が低くなる結 果となった。SIA 神田スクエアは NOI が高く水光熱費が低い環境 性能の優れたビルになっていることがわかる。

\section{CASBEE 認証の有効期限外物件と賃貸事業収益の関係}

\section{1 調査概要}

表 5 に CASBEEの有効期限外の大規模物件一覧を示す。CASBEE 取得後、一度でも有効期限が失効した物件を対象とした。対象物件 には失効後、CASBEE を再取得した物件も含まれている。全国にお ける CASBEE が失効した大規模物件は、CASBEE 新築が 4 件、自 治体版 CASBEE が 3 件、不明な物件が 2 件、CASBEE 既存が 1 件 であった。建物全体、賃貸部分ともに用途は、事務所が多かった。

\section{2 調査結果}

図 10 に大規模物件における総賃貸面積と NOI の比較を示す。認 証物件は、非認証物件と比較して NOI が高くなった。対象物件の中 でCASBEEを再取得した物件は、ゲートシティ大崎のみであった。 有効期限を過ぎても、CASBEE 認証が NOI に与える影響が示され ている。

図 11 に大規模物件における総賃貸面積と年間水道光熱費の比較 を示す。CASBEE 認証物件と非認証物件の水道光熱費は同程度とな った。ただし、ゲートシティ大崎は失効後に CASBEE を再取得し ている。取得後 $3 \sim 5$ 年以上経過し失効した CASBEE 認証物件で も、水道光熱費は高くならなかった。特に、ゲートシティ大崎およ び汐留ビルディングは水道光熱費に対する NOI が高い結果となっ た。

\section{CASBEE 不動産認定物件と一次エネルギー消費量の関係}

\section{1 調查方法}

CASBEE 不動産認定物件は、一年間における一次エネルギー消費 量の実績值を公開している ${ }^{14)}$ 。2013 年度、2014 年度に CASBEE 不動産の評価を実施した J-REIT 保有オフィスを対象に解析を行っ た。各物件の CASBEE 不動産の評価実施年度と同年の J-REIT 所 有オフィスの開示データ（1 年間分）を用いた。

表 6 に CASBEE 不動産認定物件一覧を示す。J-REIT 保有オフィ スのうち 15 件が対象となった。 $\mathrm{S}$ ランクの物件が 2 件、A ランク の物件が 13 件となった。所有形態は一棟所有もしくは共有となり、 区分所有の物件はなかった。全て CASBEE ランクの高い物件とな っている。

ただし、Jタワー、KDX 新宿ビル、新宿マインズタワーにおいて、
表 5 CASBEE 認証の大規模物件一覧（有効期限外）注2)

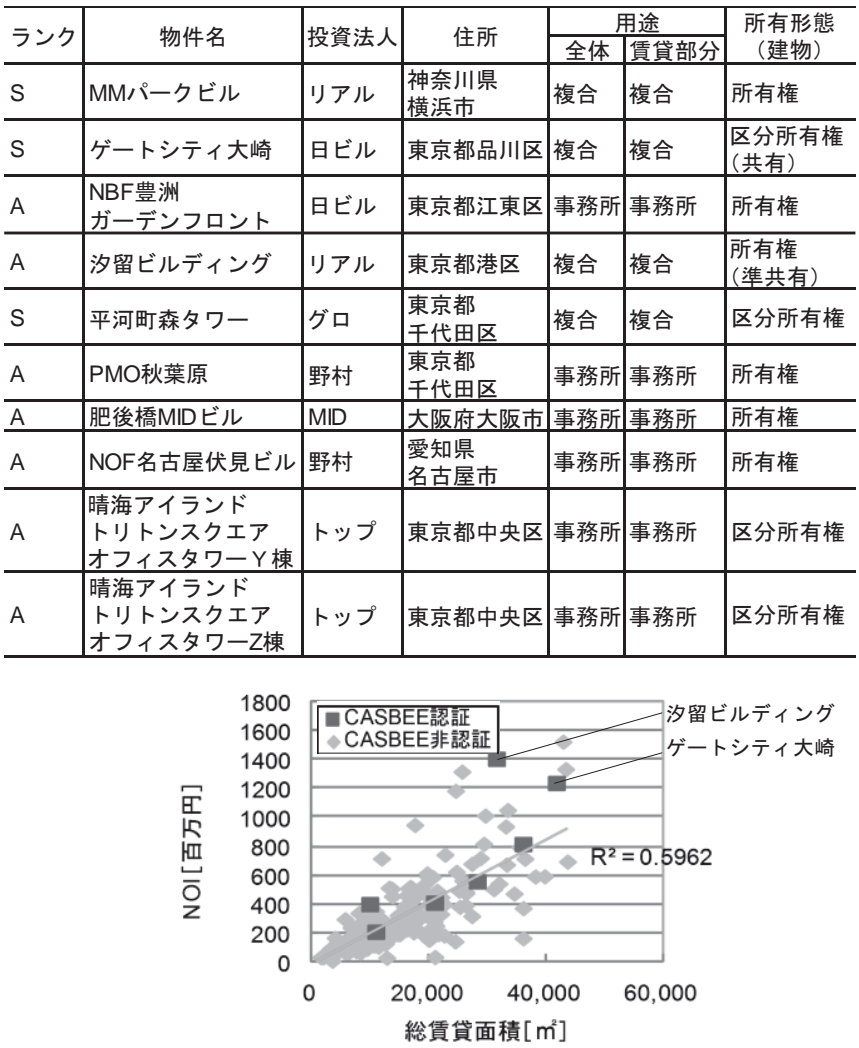

図 10 大規模物件の総貨貸面積と年間 NOI（有効期限外）

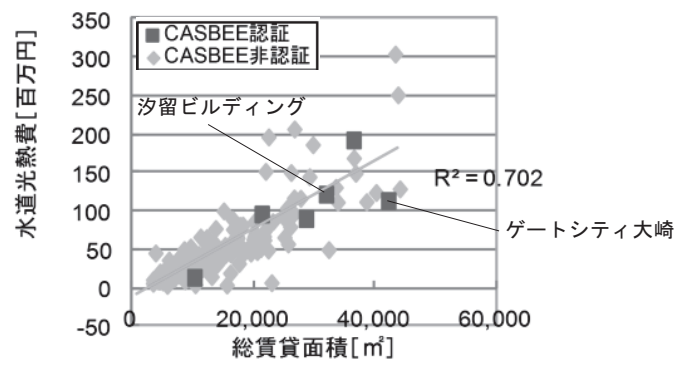

図 11 大規模物件の総賃貸面積と年間水道光熱費（有効期限外） 表 6 CASBEE 不動産認定物件一覧注2)

\begin{tabular}{|c|c|c|c|c|c|c|}
\hline \multirow{2}{*}{ ランク } & \multirow[b]{2}{*}{ 物件名 } & \multirow{2}{*}{\begin{tabular}{|l|} 
投資 \\
法人 \\
\end{tabular}} & \multirow[b]{2}{*}{ 住所 } & \multicolumn{2}{|c|}{ 用途 } & \multirow{2}{*}{$\begin{array}{c}\begin{array}{c}\text { 所有形態 } \\
\text { (建物) }\end{array} \\
\end{array}$} \\
\hline & & & & 全体 & 賃貸部分 & \\
\hline $\mathrm{S}$ & 赤坂永川ビル & ユナ & 東京都港区 & 事務所 & 事務所 & 所有権 \\
\hline & SIA 神田スクエア & SIA & $\begin{array}{l}\text { 東京都 } \\
\text { 千代田区 }\end{array}$ & 複合 & 複合 & 所有権 \\
\hline & $\begin{array}{l}\text { フフィックマークス } \\
\text { 本橋富沢町 } \\
\end{array}$ & ユナ & 東京都中央区 & 事務所 & 事務所 & 所有権 \\
\hline & $\begin{array}{l}\text { シフィックマークス } \\
\text { 汉見附 }\end{array}$ & ユナ & 東京都港区 & 复合 & 複合 & |所有権 \\
\hline & $\begin{array}{l}\text { パシフィックマークス } \\
\text { 新横浜 }\end{array}$ & ユナ & 横浜市 & 事務所 & 事務所 & 所有権 \\
\hline & 五反田TGビル & ケネ & 東京都品川区 & 務所 & 事務所 & 所有権 \\
\hline A & いちご神 & $\begin{array}{l}\text { いち } \\
\text { ご }\end{array}$ & $\begin{array}{l}\text { 東京都 } \\
\text { 千代田区 }\end{array}$ & 複合 & 複合 & 所有権 \\
\hline$\Delta$ & J タワー & SIA & 東京都府中市 & 複合 & 複合 & 所有権 \\
\hline$\Delta$ & $\begin{array}{l}\text { パシフィックマークス } \\
\text { 新宿パークサイド } \\
\end{array}$ & ユナ & 東京都新宿区 & 複合 & 合 & 所有㭚 \\
\hline 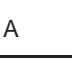 & $\begin{array}{l}\text { パシフィックマークス } \\
\text { 横浜イースト } \\
\end{array}$ & ユナ & $\begin{array}{l}\text { 神奈川県 } \\
\text { 横浜市 }\end{array}$ & 事務所 & 务所 & 个有権 \\
\hline$A$ & $\begin{array}{l}\text { パシフィックマークス } \\
\text { 江坂 }\end{array}$ & ユナ & 日市 & 複合 & 複合 & 所有権 \\
\hline & 丸ビル & ケネ & 京都府京都市 & 事務所 & 事務所 & 所有権 \\
\hline A & KDX新宿ビル & 不 & 東京都新宿区 & 複合 & 複合 & 所有権 \\
\hline A & 新宿マインス & \begin{tabular}{|l|} 
大和 \\
証券 \\
\end{tabular} & 東京都渋谷区 & 複合 & 複合 & $\begin{array}{l}\text { 所有権 } \\
(\text { 共有) }\end{array}$ \\
\hline & KDX小林道修町ビル & 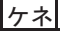 & 阪府大阪市 & 複 & 複合 & 所有権 \\
\hline
\end{tabular}


一次エネルギーに対する水道光熱費 $\left[\right.$ 円 $\left./ \mathrm{m}^{2}\right]$ が顕著に高かった。こ れらの 3 物件は地域冷暖房を導入しており、一次エネルギー消費量 に対する水道光熱費の割合が、一般の建物と比較して高くなったと 考えられる。そこで、解析対象は地域冷暖房を導入していない CASBEE 不動産認定物件 12 件とした。

\section{2 解析結果}

図 12 に一次エネルギー消費量の実績值と水道光熱費の関係を示 す。地域冷暖房を導入していない CASBEE 不動産認証物件におい て、水道光熱費と一次エネルギー消費量の実績值にはある程度の正 の相関がみられた。今回の解析では契約料金などの影響は加味され ておらず、今後考慮する必要がある。

\section{7. まとめ}

本研究では、CASBEE 認証及び東京都トップレベル事業所認定物 件がオフィスビルの賃貸事業収益（NOI）及び水光熱費に与える影 響を把握することを目的とした。J-REIT 所有オフィスの 2014 年度 の開示データを用いて、全国で貨貸面積 $50,000 \mathrm{~m}^{2}$ 以下のオフィス 651 件の基本情報および収益や費用を把握した。その結果、以下の ことが明らかになった。

1 ）建物全体の延床面積が $10,000 \mathrm{~m}^{2}$ 以上の大規模物件において、 トップレベル事業所認定物件は、非認定物件と比較して NOI が 高く、水道光熱費が同等となる傾向が見られた。

2） 2014 年の時点で有効期限内にある CASBEE 認証物件を解析 した。建物全体の延床面積が $10,000 \mathrm{~m}^{2}$ 以上の大規模物件にお いて、認証物件は、非認証物件と比較して NOI が高かったが、 水道光熱費も高くなる傾向が見られた。特に、建物全体の用途 が複合用途かつ一棟所有の物件における水道光熱費は、その他 の大規模物件と比較して高く、地域冷暖房および店舗等による 影響を大きく受けたと考えらえる。建物全体の延床面積が 3,00 $0 \mathrm{~m}^{2}$ 以上 $10,000 \mathrm{~m}^{2}$ 以下の中規模物件において、認証物件は非 認証物件と比較して NOI が同等で水道光熱費が低くなる傾向 が見られた。

3 ） CASBEE 認証物件の中で、一度でも有効期限が失効した物件 を対象に解析を行った。対象物件には失効後、CASBEE を再取 得した物件も含まれている。建物全体の延床面積が $10,000 \mathrm{~m}^{2}$ 以上の大規模物件において、認証物件は、非認証物件と比較し てNOI が高く、水道光熱費が同等となる傾向が見られた。

4） CASBEE 不動産認定物件の一次エネルギー消費量の実績值 （単位面積当たり）と水道光熱費には中程度の正の相関がみら れた。ただし、地域冷暖房を導入している物件は解析から除い

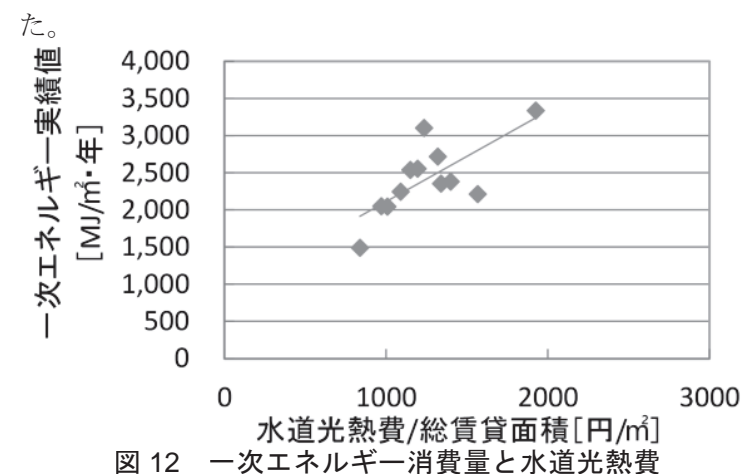

\section{謝辞}

本報の内容は、スマートウェルネスオフィス研究委員会 (委員長： 村上周三） 不動産調查部での研究活動の一部である。ご協力頂いた 皆様に心より感謝申し上げます。また、早稲田大学理工学研究所の プロジェクトとして研究を行った。

\section{参考文献}

1）経済産業省：エネルギー白書 2015 ，第二部，第一章，2015

2) CASBEE HP: http://www.ibec.or.jp/CASBEE/about_cas.htm, 2015.12.02参照

3) LEED HP: http://www.usgbc.org/LEED/, 2016.8.27参照

4）東京都環境局：総量削減義務と排出量取引制度における優良特定地球温 暖化対策事業所の認定ガイドライン（第一区分事業所）, 2014.4

5）環境不動産ポータルサイト：

http://tochi.mlit.go.jp/kankyo/about/index.html, 2016.8.27参照

6）国土交通省：環境不動産に関する企業の意識調査, 2011.3

7) Miller Norn, Spivey Jay, Florance Andrew: Does Green Pay Off ,

Journal of Real Estate Portfolio Management, 2008

8) Quigley $ら$ : 'Doing Well by Doing Good?', Green Office Buildings, 2009

9）吉田 淳, 大西 順一郎：環境マネジメントの経済性分析 東京23区オフィ スビルにおける環境認証取得有無と新規賃料の関倸 ヘドニック・アプロ 一チおよび傾向スコアをもちいた分析, 2015.7.16

10）伊藤 雅人：不動産マーケットにおけるCASBEE・知的生産性評価の経 済効果, 2015.2 .13

11）武藤ら：J-REIT 所有オフィスにおける環境性能評価指標の不動産運用 一の影響, 日本建築学会大会学術講演㤦概集, 環境工学 II , pp.1099 1100,2014

12）網代ら：投資用不動産を対象とした環境不動産に関する実態調查, 日本 建築学会大会学術講演梗概集，建築社会システム, pp.41〜42, 2014

13）東京証券取引所：Jリートがわかる本，東急エージェンシー, 2013.10 .7

14）国土交通省：環境不動産に関する企業の意識調査, 2011.3 http://tochi.mlit.go.jp/kankyo/info/data/konndann3/ss31\%20deta.pdf 2016.3.28参照

15）東京都環境局 HP気候変動対策 大規模事業所における対策 トップレ心゙ ル事業所 トップレベル事業所等の認定実績:

http://www.kankyo.metro.tokyo.jp/climate/large_scale/toplevel/cat8317. $\mathrm{html} 2015.12 .02$ 参照

16）有価証券報告書：MCUBS MidCity投資法人, SIA不動産投資法人，アク ティビア・プロパティーズ投資法人，いちごオフィスリート投資法人，イ ンヴィンシブル投資法人, オリックス不動産投資法人, グローバル・ワン 不動産投資法人，ケネディクス・オフィス投資法人，ジャパンエクセレン 卜投資法人，ジャパンリアルエステイト投資法人，トップリート投資法人， プレミア投資法人，ユナイテッド・アーバン投資法人，阪急リート投資法 人，森トラスト総合リート投資法人，森ヒルズリート投資法人，大和証券 オフィス投資法人，東急リアル・エステート投資法人，日本ビルファンド 投資法人，日本プライムリアルティ投資法人，日本リート投資法人，福岡 リート投資法人, 平和不動産リート投資法人, 野村不動産マスターファン ド投資法人, 2014.1〜2014.12

注

注 1）NOI（Net Operating Income）は純収益と訳されるが、本論文で対 象としているのはREIT であるため、賃貸事業収益と訳すことにした。

注 2）表における投資法人（略称）の正式名称を以下に示す。 トップ：トップリート投資法人、

日ビル：日本ビルファンド投資法人

森ヒルズ : 森ヒルズリート投資法人

リアル：ジャパンリアルエステイト投資法人

プレミア:プレミア投資法人

エク：ジャパンエクセレント投資法人

ユナ：ユナイテッド・アーバン投資法人

ケネ：ケネディクス・オフィス投資法人

大和証券 : 大和証券オフィス投資法人

グロ：グローバル・ワン不動産投資法人

SIA : SIA 不動産投資法人

いちご：いちごオフィスリート投資法人

野村 : 野村不動産マスターファンド投資法人

MID : MCUBS MidCity 投資法人

注 3）参考文献 16)について、本文の一部では 2013.1～2013.12 における情 報を活用している。 


\title{
EFFECTS OF CASBEE AND TOKYO METROPOLITAN GOVERNMENT \\ TOP LEVEL CERTIFICATES ON THE NET OPERATING INCOME \\ AND UTILITY EXPENSES IN J-REIT OWNED OFFICE BUILDINGS
}

\author{
Gen AOKI*, Shin-ichi TANABE** and Toshimasa ITAYA*** \\ * Former Grad. Stud., Waseda University \\ ** Prof., Dept. of Architecture, Waseda University, Dr.Eng. \\ *** Property Data Bank, Inc., Dr.Eng.
}

The purpose of this research is to evaluate the economic value of certification of green buildings based on $\mathrm{j}$-reit (Japan Real Estate Investment Trust) owned office buildings. In the recent years, assessment systems for the environmental performance of buildings are being widely used in Japan. Some analyses were conducted in Japan to investigate whether green building certificates have a positive influence on the contract rent. However we need to investigate profits and expenses of the real estate rent to clearly explain the economic benefits of green buildings.

In this research, we analyze the office building annual data in Japan which was disclosed by J-REIT. Operating benefits and utilities costs of 657 buildings in January 2014 - December 2014 was analyzed. Regarding the objective office, the total leased area is under $50000 \mathrm{~m}^{2}$ and each building was divided into green building certified or Noncertified. Subject green building certifications are Tokyo Top-Level Business Facility and CASBEE (Comprehensive Assessment System for Built Environment Efficiency).

The net operating incomes of Top-Level Business Facility or CASBEE certified office buildings over $10000 \mathrm{~m}^{2}$ of total building area are bigger than that of not certified office buildings. The utilities costs of Top-Level Business Facility certified office buildings are the same as that of not certified office buildings, but the utilities cost of CASBEE certified office buildings is bigger than that of not certified office buildings. The net operating incomes of CASBEE certified office buildings over $3000 \mathrm{~m}^{2}$ and less than $10000 \mathrm{~m}^{2}$ of total building area are bigger than that of not certified office buildings. The utilities costs of CASBEE certified office buildings over $3000 \mathrm{~m}^{2}$ and less than $10000 \mathrm{~m}^{2}$ are the same as that of not certified office buildings. The net operating incomes of expired CASBEE certified office buildings over $10000 \mathrm{~m}^{2}$ of total building area are bigger than that of not certified office buildings. The utilities costs of expired CASBEE certified office buildings are the same as that of not certified office buildings. Using these results, the environmental performance of Top-Level Business Facility certified office buildings over $10000 \mathrm{~m}^{2}$ of total building area and expired CASBEE certified office buildings over $10000 \mathrm{~m}^{2}$ of the area, CASBEE certified office buildings over $3000 \mathrm{~m}^{2}$ and less than $10000 \mathrm{~m}^{2}$ of the area may be high in the value of the real estate.

The utilities costs of buildings are not always related to the energy consumption, because an energy source, a type of contract and a contract fee are different in each building. In this survey, the primary energy consumption of CASBEE real estate buildings is correlated with the utilities cost of the buildings. The objective buildings do not install the regional air-conditioning. 